\title{
Skin Response Category
}

National Cancer Institute

\section{Source}

National Cancer Institute. Skin Response Category. NCI Thesaurus. Code C117677.

A classification of skin response data. 